\title{
IMPROVING SELF-CARE INDEPENDENCY \\ OF TYPE 2 DIABETES MELLITUS PATIENTS \\ BASED ON LASALLIAN EDUCATION MODEL
}

\section{Peningkatan Kemandirian Perawatan Diri Penderita Diabetes Mellitus Tipe 2 Berbasis Model Pendidikan Lasallian}

\author{
Annastasia S. Lamonge, Wahyuni Langelo, Natalia Rakinaung \\ Fakultas Keperawatan, Universitas Katolik De La Salle Manado \\ Email: alamonge@unikadelasalle.ac.id
}

\begin{abstract}
ABSTRAK
Pendahuluan. Penyakit Diabetes Mellitus (DM) merupakan masalah global yang tidak hanya membawa penderitaan bagi penderitanya tapi juga berdampak bagi keluarga, lingkungan dan komunitas. Tujuan penelitian ini adalah untuk menganalisis efektivitas pendidikan kesehatan Lasallian terhadap peningkatan kemandirian penderita DM tipe 2 dalam perawatan diri. Metode. Desain yang digunakan adalah Pre-Experiment dengan target populasi penderita DM tipe 2.12 partisipan direkrut dalam penelitian dengan teknik purposive sampling. Uji t-berpasangan dan uji Wilcoxon digunakan untuk menguji efektivitas pendidikan kesehatan. Hasil. Hasil uji bivariate tentang pengetahuan dan sikap sebelum dan sesudah dilakukan pendidikan kesehatan berbasis Lasallian menunjukkan hasil yang signifikan dengan $\rho$-value 0,016 ( $p$-value $<\dot{\alpha} 0,05$ ). Hasil penelitian tentang kemandirian penderita DM tipe2 dalam perawatan diri sebelum dan sesudah dilakukan pendidikan kesehatan berbasis pendidikan Lasallian menunjukkan hasil yang signifikan dengan $\rho$-value 0,001 (p-value $<\alpha ́ \alpha, 01$ ). Diskusi. Transformasi perilaku/kebiasaan oleh suatu program pendidikan kesehatan harus memiliki 3 unsur penting yaitu menyentuh aspek kognitif, aspek keterampilan serta emosi dari partisipan hingga mampu memotivasi dan meningkatkan kesadaran diri, ketaatan pada manajemen perawatan diri dan peningkatan kualitas hidup.
\end{abstract}

Kata kunci: DM tipe-2,Lasallian Model, Pengetahuan, Sikap, Kemandirian perawatan diri

\section{ABSTRACT}

Introduction. Diabetes Mellitus (DM) is a global problem that not only brings misery for the sufferer but also has implications for families, neighborhoods and communities. The objectives of this study was to analyze the effectiveness of Lasallian health education in order to increased the self-care independency of people with type 2 diabetes mellitus (DM). Methods. Research design of this study was Pre-Experiment with target population patients with type 2 DM. 12 participants were recruited in the study with purposive sampling technique. Paired t-test and Wilcoxon test were used to test the effectiveness of Lasallian health education. Results. The bivariate test results of knowledge and attitudes before and after giving the Lasallian health education showed significant results with $\rho$-value of 0.016 ( $p$-value $<\dot{\alpha} 0.05$ ). Research result of self-care independency of type 2 diabetic patients in before and after giving Lasallian health education showed significant result with $\rho$-value of 0.001 (p-value $<\dot{\alpha} 0: 01$ ). Discussion. Transformation of people behavior or habit by a health education program should have three important determinants, there are cognitive, affective and psychomotor aspects of participants to motivate and increase self-awareness, and adherence of self-care management and improving of quality of life.

Keywords: Type 2 DM, Lasallian Model, Knowledge, Attitude, Self-care independency

\section{INTRODUCTION}

Diabetes Mellitus (DM) is a global problem that not only brings misery for the sufferer but also has implications for families, neighborhoods and communities. The number of deaths due to diseases of diabetes and its complications (heart disease and stroke) has been the leading cause of death in the world and in Indonesia.

Data show that the number of people with Diabetes Mellitus in 2013 reached 383 million people. The figure has far exceeded the predictions of the International Diabetes Federation (IDF) and the World Health Organization (WHO) for 2030 with 366 million people. Indonesia was 4 th ranked in the world for most cases of diabetic patients after the US and Japan. The prevalence of DM patients in urban areas in Indonesia in 15 years is $5.7 \%$ and the North Sulawesi province is one of the provinces with the highest number of cases of Diabetes Mellitus (Riskesdas 2007). Statistical 
data of General Hospital Prof. Dr. RD Kandou Manado noted there is a significant increase in the number of cases from 11. 084 in 2011 become 16.386 in 2012. The number of cases of DM increased significantly where DM people require special handling, considering DM can't be cured and is also a pre-cause for various diseases such as heart disease and stroke.

Many factors influence the occurrence of DM. Unhealthy lifestyle is one of the main factors causing the occurrence of type $2 \mathrm{DM}$. Consumptive pattern of society to fast food, lack of exercise and smoking behavior activity are partly an example of the lifestyle of society today's. Minahasa community behavior patterns in the consumption of meat and some types of foods that are high in calories is one of the factors that contribute to increase the number of Diabetes cases in North Sulawesi.

DM can't be cured but can be controlled with pharmacologic therapy and non-pharmacologic. The only way to prevent complications of diabetes is to control blood sugar levels that can be done by running a new lifestyle for people with diabetes, includes: an appropriate diet regular exercise, use of medication compliance, blood sugar control, regular foot examinations, stress processing and do not smoke. Therefore, health education is needed not only to improve knowledge but must be able to involve patients in decision making and planning, and to motivate patients to autonomously behave in a healthy lifestyle. Currently the Indonesian government through the health department already has a non-communicable disease control program including control of DM, however, the effectiveness of this program has not been fully demonstrated and show significant changes. Various health education programs for people with diabetes also have been there, but it's still limited to efforts to increase knowledge and skills of people with diabetes. The topic of health education materials is still limited to one or several lifestyle for people with diabetes. Complete health education program for people with diabetes are given and continuous, involving a team of health care providers and oriented on the involvement of patients in decision-making, planning treatment and selfreliance in the care of itself.

Lasallian health education is an innovation that is adapted from the Lasallian educational model, which is also the basis of the provision of education at the Catholic University De La Salle Manado. Lasallian Health Education distinctiveness is the pedagogy used holistic, namely: "Teaching Mind, Heart Touching, Transforming Life". "Teaching Mind" describes the content of the material will be complete and comprehensive, not only to increase knowledge but also skills of people. "Touching Heart" describes the method used, which involves the participation of the people with DM, able to touch the soul and are able to motivate people with diabetes. And "Transforming Life" drawn from the outcomes to be achieved is a change of behavior in the form of independence in self-care and improved quality of life.

\section{METHODS}

The research used experimental design (pre-experiment) pre-post test. This design was used to determine the effectiveness of the intervention given before and after the intervention. Data from qualitative: Focus group discussion (FGD) also used to improve the analysis.

Participants in this study were patients with type $2 \mathrm{DM}$ who were include in working area of Public health centers TumintingManado. The inclusion criteria were patients with type $2 \mathrm{DM}$ and exclusion criteria diabetic patient with insulin therapy. The participants enrolled in the study were 13 people. However, the data analysis used only the data 12 participants because one participant stated dropout due to not complete the health education program.

Data collection technique used a questionnaire with guidance from researchers (guided interviews) and through Focus Group Discussion. This study used four main instruments. The first instrument was an instrument profile of participants that contains of demographic data of respondent. 
The second instrument was an instrument of knowledge and attitude, this instrument was a questionnaire which consisting of 20 multiple choice questions. This instrument was made by a team of researchers and already used in previous studies and have tested the validity and reliable for measuring knowledge and attitude of DM patients. The third instrument was an instrument of self-care behaviors. This instrument was a questionnaire created by Deborah Toobert et al (2000) with the title "Summary of Diabetes Self-Care Activities" (SDSCA). The fourth Instrument was the instrument that used for Focus Group discussion (FGD), this instrument contains questions that guiding the reflection and group sharing. The result of group discussion was verbal expression of each participant.

The paired t-test used to determine the effectiveness of pre and post intervention of self-care independency of diabetic patients. Wilcoxon test was used to measure the effectiveness of Lasallian health education in increased knowledge and attitudes. Wilcoxon test was used because the data was not normally distributed.

Researcher applied for a permit before performing research studies in the clinic Tuminting-Manado. Researchers provide assurance to participants by using anonymous respondents in instrument sheet. The information that provided by the participants were kept confidential, except for specific data group that will be reported as a result of research.

\section{RESULTS}

The table 1 shows that knowledge and attitudes before and after Lasallian health education program have significant value with $\rho$ value 0.016 ( $\mathrm{p}$ value $<\alpha$ 0.05 ).

Table 2 shows that the independence of people with type $2 \mathrm{DM}$ in the self care before and after Lasallian health education have significant value with $\rho$ value 0,001 (p value $<\alpha$ 0:01).

\section{DISCUSSION}

The main purpose of this study was to determine the effectiveness of Lasallian health education in improving knowledge, and especially self-care independency and attitude of DM patients in self-care. The assumption is that the participants will have increased in knowledge, attitude, and self-care independency after following the Lasallian health education. Wilcoxon statistical test results for the knowledge and attitudes obtained $\mathrm{p}$ value 0.016 , which means Lasallian health education effectively increased the knowledge and attitude of patients with type 2 diabetes mellitus. Similar results were also obtained from the paired t test for self-care independency of diabetic patient, with $\mathrm{p}$ value of 0.001 which means Lasallian health education effectively increased the self-care independency of type 2 diabetes patients.

These results are similar with previous studies was conducted by Davies MJ in 2008

Table 1. Knowledge and attitude in Pre-Post test of Lasallian Health Education Program

\begin{tabular}{lcccc}
\hline \multicolumn{1}{c}{ Variable } & $\mathbf{n}$ & Mean Rank & $\mathbf{Z}$ & P value \\
\hline Pre test of Knowledge and attitude & 12 & 2.50 & -2.399 & 0.016 \\
\hline Post test of Knowledge and attitude & \multicolumn{4}{c}{5.31} \\
\hline
\end{tabular}

Table 2. Self-care independency of Patients with type 2 DM in Before and After Lasallian Health Education Program

\begin{tabular}{lcccc}
\hline \multicolumn{1}{c}{ Variable } & $\mathbf{n}$ & Mean & t & P value \\
\hline Pre test of self-care independency & 12 & 41.6667 & -4.380 & 0.001 \\
\hline Post test of self-care independency & \multicolumn{4}{c}{70.0833} \\
\hline
\end{tabular}


and by the Duke 2009 and Oftedal on 2011. Overall the results of their study found an increased knowledge, attitude and behavior of even significantly of quality of life in the study group were given health education. However, in other studies showed different results, where health education was not effective for lowering HbAlc. This proves that the health education remains one of the primary means for health workers in the prevention and control of diabetes disease. A health education should be designed and delivered with the right methods to able to increase their knowledge and skills in self-care and to improve the quality of life.

Lasallian health education is health education program specifically designed for people with type 2 diabetes mellitus based on Lasallian health education models. Particularities of this education program are the pedagogy used which is "Teaching Mind, Touching Heart, and Transforming Life". In this study "Teaching Mind" describes as the content of the material that complete and comprehensive, not only to increase knowledge but also skills of people. "Touching Heart" describes the methods to used, the method of reflection and sharing expected to touch people through self-reflection and sharing experiences and feelings. These methods are able to touch the soul and are able to motivate people to make commitments and resolutions in themselves. And "Transforming Life" drawn from the outcomes to be achieved in order to change behavior/pattern in new habits with form of self-care independency and improving of quality of life.

Changing a habit is not that easy, that is need an external and internal approaches (motivation) to be able to establish a pattern of new behavior/habits. Habit according to Stephen R. Covey (1989) is the intersection between knowledge (knowledge concerning what to do and why), skills (skills, with regard to how to do) and desire (desire, in concerning of want to do).

Through this study, researchers found a pattern of behavior by the transformation of a health education program. The health education in this study was designed not only to provide knowledge for the participants but also the active involvement of each participant to demonstrate the way of self-care skills such as demonstrating of activity/exercise for people with diabetes, how to measure the blood glucose by themselves and the way to taking care their foot. This method is concerning in cognitive (knowledge), and psychomotor (skills) of the participants. However, to achieve changes in behavior or habits (habit), a health education program needs to use a method that is capable to made strong intention of people to change themselves (desire).

In this study, methods was used are discussion and reflection. With this method the participants are given some time to reflect on themselves about all the experience that happened and comparing it with the contents of the material received. It is believed to touch the emotions of the participants and raises selfawareness (awareness) and the desire to change them also sharing method is a method used in this study in which participants were given the opportunity to listen to each other and share experiences based on existing guiding question. This method is considered to be a container load shedding and increase the feeling of confidence that they are not alone and each has shortcomings or strengths that have meaning.

In the end, after having the knowledge, skills and self-awareness, participants are easier to do medicine adherence with life in healthy lifestyle for people with diabetes (diet, activity, regularity of treatment, blood glucose control, foot examination and not smoking). This is evident from the results of the focus group discussion, he majority of participants were able to implement the new lifestyle DM patients have good support from their family. Although there were some inhibits circumstances such as the 'forgotten', physical weakness and social conditions that make some of the participants do not run good self-care in independently. Researcher expected that the participants have an independent habit to be able to control the levels of blood glucose and can prevent diabetes complications and improve quality of life. However, due to limitations of the study period, researchers have not been able to examine the effectiveness of health education 
on quality of life. It is also necessary to conduct further evaluation of the independence of selfcare patients in time period on 1-3-6 months after health education.

\section{CONCLUSION}

Lasallian Health educations are effectively improves knowledge and attitudes of people with diabetes in performing self-care. Lasallian Health educations are effectively increases the independence of people with diabetes in performing self-care.

\section{RECOMMENDATION}

For health workers can implement and develop health education for patients with type 2 diabetes mellitus that can be sustained health education. For patients with type 2 diabetes mellitus can be more proactive in searching for the source of the latest information related to independent self-care as well as utilize existing in optimum capacity that may support either in the public health center, family and spiritual. Also maintain and improve adherence to diabetes care management program. For further research can be examined further by the method times series to measure the effect of this health education on behavior/ self-care independence and develop design of this study using control groups to measure the effectiveness of this program if it is better than the conventional health education programs.

\section{REFERENCES}

Covey, S.R., 1989. The 7 Habits of Highly Effective People an Approach to Solving Personal and Professional Problems.

Davies, M.J. et al. 2008. Effectiveness of the diabetes education and self management for ongoing and newly diagnosed (DESMOND) programme for people with newly diagnosed type 2 diabetes: cluster randomised controlled trial. BMJ (Clinical research ed.), 336(7642), pp.491-5. Available at: http://www.bmj. com/content/336/7642/491?ijkey $=714 \mathrm{a} 0$ 1046f7ab4746e75ce5237e7a6c8836376 bd\&keytype $2=$ tf_ipsecsha.

Duke SAS, Colagiuri S, C.R. 2009. Individual Patient Education for People with Type 2 Diabetes Mellitus. In The Cochrane Collaboration. JohnWiley \& Sons, Ltd.

Oftedal 2011. Motivation for Self-management Among Adults with Type 2 Diabetes. University of Stavanger. Norwey.

Toobert, D.J., Hampson, S.E. \& Glasgow, R.E. 2000. The Summary of Diabetes SelfCare. Diabetes Care Journal 23(7), pp. 943-950. 